\title{
Progress in Mapping and Cloning Qualitative and Quantitative Resistance Against Phytophthora infestans in Potato and Its Wild Relatives
}

\author{
Ingo Hein • Paul R. J. Birch • Sarah Danan • \\ Véronique Lefebvre • Damaris Achieng Odeny • \\ Christiane Gebhardt • Friederike Trognitz • \\ Glenn J. Bryan
}

Received: 10 June 2009 / Accepted: 17 June 2009 /

Published online: 25 July 2009

(C) EAPR 2009

\begin{abstract}
Cultivated potato is susceptible to many pests and pathogens, none of which is more of a threat to potato agriculture than the late blight disease, caused by the oomycete Phytophthora infestans (Mont.) de Bary. To date all efforts to thwart this most adaptive of pathogens have failed, and early attempts to deploy ' $R$ genes' introgressed from the wild Mexican hexaploid Solanum demissum ended in abject failure. With the advent of facile gene mapping and cloning, allied to knowledge of plant resistance gene structure, renewed efforts are leading to mapping and isolation of new sources of late blight resistance in potato wild species, many of which are being performed under the auspices of the BIOEXPLOIT project (Sub-project 2). We document recent advances in late blight resistance gene mapping and isolation, and postulate how these genes, allied to knowledge of pathogen effectors and their recognition specificity, may greatly enhance our chances of halting the progress of late blight disease in potato crops worldwide.
\end{abstract}

I. Hein · G. J. Bryan $(\bowtie)$

Genetics Programme, Scottish Crop Research Institute (SCRI), Invergowrie, Dundee DD2 5DA, UK e-mail: glenn.bryan@scri.ac.uk

P. R. J. Birch

Plant Pathology, Scottish Crop Research Institute (SCRI), Invergowrie, Dundee DD2 5DA, UK

S. Danan · V. Lefebvre

Institut National de la Recherche Agronomique, INRA UR 1052 GAFL Génétique et Amélioration des Fruits et Légumes, B.P. 94, 84140 Montfavet, France

D. Achieng Odeny $\cdot$ C. Gebhardt

Max Planck Institute for Plant Breeding Research, Carl-von-Linné Weg 10, 50829 Köln, Germany

F. Trognitz

Bioresources Department, Austrian Research Centers GmbH-ARC, A-2444 Seibersdorf, Austria 
Keywords Cloning - Gene mapping · Late blight · Pathogen effectors ·

Recognition specificity · Resistance breeding - Solanum tuberosum . Wild potato

\section{Introduction}

Since the dawn of potato genetics, several resistances against the most serious disease, late blight, caused by the oomycete Phytophthora infestans (Mont.) de Bary, have been identified in wild potato species, with an increasingly large number being identified in recent years. Moreover, significant progress has been made in mapping and isolating genes conferring resistance to P. infestans and, with the availability of pathogen effectors, recognition specificity of resistance $(R)$ genes can now be determined at a molecular level. However, many resistances to this rapidly evolving and highly adaptable pathogen have been quickly overcome by pathogen variations and truly durable resistance against $P$. infestans remains elusive. This state of affairs has led to new screens of potato germplasm for potentially novel sources of $P$. infestans resistance, several of which are being studied in the context of the BIOEXPLOIT project.

High quality maps, both genetic and physical, are indispensable to the localization, identification, and analysis of disease resistance genes. The main objectives of BIOEXPLOIT Sub-project 2 are to generate potato populations segregating for novel $P$. infestans resistances and to map and isolate the genes present. Other BIOEXPLOIT sub-projects, reported elsewhere in this issue of Potato Research, aim to identify and study pathogen-derived effectors, respectively. Linking the different BIOEXPLOIT strands, $P$. infestans effectors derived from these studies are now being increasingly incorporated into the characterisation of $R$ gene specificity. In this paper, we provide an overview of the ongoing work on mapping potato resistance loci to $P$. infestans, isolating the underlying genes, and put these efforts into the context of previous work on analyzing $P$. infestans resistance genes.

\section{Previous $P$. infestans Resistance Breeding}

Early potato breeding for $P$. infestans resistance resulted in introgression of 11 resistance (designated $R 1-R 11$ ) genes from the Mexican hexaploid species $S$. demissum (Black et al. 1953; Malcolmson and Black 1966). However, as early as in the 1950s breeders realized that deployment of these genes, even in combination, did not provide durable resistance to the rapidly changing populations of $P$. infestans. In the 1960s, the parallel breakdown of three $R$ genes was witnessed following the release of the potato cultivar Pentland Dell, containing $R 1, R 2$ and $R 3$. Released in 1961, Pentland Dell succumbed to extensive infection by new late blight races only 6 years later. This was prior to the introduction of the $P$. infestans A2 mating type, and a number of highly virulent pathogen genotypes, following a drought in the late 1970s (Drenth et al. 1994). Up to this point $P$. infestans populations of the A1 mating type in Europe showed little variation and isolates overcoming $R 1, R 2$ and $R 3$ had not been identified. Importantly, it appears that selection pressure imposed upon the pathogen population by the widespread use of Pentland Dell increased the frequency of more complex 
isolates (Shattock et al. 1977). Alongside other studies, Pentland Dell has illustrated the risks of relying on host resistance for disease control without due consideration of how the pathogen population may respond to its deployment, and has also sparked intensive searches for potentially more durable forms of resistance that focus on $R$ genes and quantitative sources of resistance from other wild, P. infestans resistant, Solanum species (Bradshaw et al. 2004a; Bradshaw and Birch 2006).

\section{Mapping of Resistance Genes}

The majority of $S$. demissum blight resistance genes ( $R 1$ to $R 11)$, have been mapped (Table 1), and are primarily located on linkage groups (LG) IV $(R 2), \mathrm{V}(R 1)$ and XI $(R 3 a, R 3 b$ and $R 5-R 11)$ (Leonards-Schippers et al. 1992; Li et al. 1998; Huang et al. 2004; Huang 2005; Park et al. 2005a; Bradshaw et al. 2006a). Following the observation that the race-specific $R$ genes from $S$. demissum did not confer durable resistance to $P$. infestans, extensive screening programmes of potato gene banks for new sources of resistance have been conducted. Subsequent population development and mapping have led to the localization of several Rpi (for Resistance to $\underline{P}$. infestans) genes from wild Solanum species (Table 1). Good examples of these are: S. pinnatisectum (Kuhl et al. 2001), S. bulbocastanum (Naess et al. 2000; Song et al. 2003; van der Vossen et al. 2003; Park et al. 2005a, b; van der Vossen et al. 2005) from Mexico and S. berthaultii (Rauscher et al. 2006), S. microdontum (Sandbrink et al. 2000), S. mochiquense (Smilde et al. 2005) and S. paucissectum (Villamon et al. 2005) from other South American countries. Moreover, the primitive cultivated diploid $S$. phureja has been described to contain valuable resistance (Śliwka et al. 2006). These efforts have shown that wild and primitive cultivated potato germplasm are a rich source of novel resistances to $P$. infestans that can be exploited in potato breeding programmes.

Some of these resistances are being studied in the context of the BIOEXPLOIT project. For example, Rpi-mcql from S. mochiquense maps to the distal region of the long arm of chromosome IX, close to the location of a previously mapped $P$. infestans resistance in tomato (Smilde et al. 2005). Similarly, blight resistance in the non-tuberising species $S$. caripense is currently being studied. Extremely low levels of genetic variations have required the development of SNP-based allelespecific markers (Nakitandwe et al. 2007a) and aided the construction of a map that has positioned the Rpi gene to LG IX (Nakitandwe et al. 2007b). These findings suggest that research groups mapping genes to locations of previously mapped Rpi genes can make extensive use of information from these previous findings, a key feature of the BIOEXPLOIT project, which should help to accelerate gene isolation.

Further population development is ongoing within the BIOEXPLOIT project, whereby several species are being used to establish crosses for future mapping work (E. Ritter, A. Carrasco, V. Lefebvre, personal communication; Danan et al. 2009). These species include $S$. boliviense, S. gourlayii, S. avilesii, S. spegazzinii, S. sparsipilum, $S$. venturii and $S$. berthaultii and other ones. In addition, an integrated linkage map of the potato transcriptome has been constructed utilizing cDNA-AFLP technology, and subsequently anchored to the 'bins' of the Ultra High Density 
Table 1 Late blight resistance genes, their origin, linkage group (LG) and cloning strategy

\begin{tabular}{|c|c|c|c|c|c|}
\hline Gene & Origin & LG & $\begin{array}{l}\text { Cloning } \\
\text { strategy }\end{array}$ & $\begin{array}{l}\text { Additional } \\
\text { information }\end{array}$ & References \\
\hline
\end{tabular}

\section{$R$ genes from $S$. demissum}

R2 S. demissum

Rpi-dmsf1 S. demissum

R1

$\begin{array}{ll}R 3 a & \text { S. demissum } \\ \text { R3b, R5- } & \text { S. demissum } \\ \text { R11 } & \end{array}$

4 Allele mining Cloned
$4 \quad$ Map based and allele mining

Potential ortholog Hein et al. 2007 of Rpi-blb3

Cloned

Leonards-Schippers et al. 1992; Ballvora et al. 2002

Cloned

Huang et al. 2004; Huang et al. 2005

Alleles of $R 3 a$

El-Kharbotly et al. 1996; Huang et al. 2004; Huang 2005; Bradshaw et al. $2006 b$

\section{$\boldsymbol{R}$ genes from other wild Solanum species}

\begin{tabular}{|c|c|c|c|c|c|}
\hline R2-like & unknown & 4 & Allele mining & $\begin{array}{l}\text { Ortholog of } \\
\text { Rpi-blb3 }\end{array}$ & Lokossou et al. 2009 \\
\hline Rpi-abpt & S. bulbocastanum & 4 & Allele mining & $\begin{array}{l}\text { Ortholog of } \\
\text { Rpi-blb3 }\end{array}$ & Lokossou et al. 2009 \\
\hline Rpi-blb3 & S. bulbocastanum & 4 & Map based & $\begin{array}{l}\text { Ortholog of } \\
\text { Rpi-blb3 }\end{array}$ & Lokossou et al. 2009 \\
\hline Rpi-bst1 & S. brachistotricum & 4 & $\begin{array}{l}\text { Map based } \\
\text { and allele } \\
\text { mining }\end{array}$ & $\begin{array}{l}\text { Potential ortholog } \\
\text { of Rpi-blb3 }\end{array}$ & $\begin{array}{l}\text { J. Jones and } \mathrm{Z} \text {. Chu, } \\
\text { personal communication }\end{array}$ \\
\hline Rpi-mcd & S. microdontum & 4 & Map based & $\begin{array}{l}\text { Accession } \\
\text { MCD167 }\end{array}$ & Sandbrink et al. 2000 \\
\hline Rpi-mcdl & S. microdontum & 4 & Map based & $\begin{array}{l}\text { Potential ortholog } \\
\text { of Rpi-blb3 }\end{array}$ & Tan et al. 2008 \\
\hline Rpi-blb2 & S. bulbocastanum & 6 & Map based & Cloned & van der Vossen et al. 2005 \\
\hline Rpil & S. pinnatisectum & 7 & Map based & & Kuhl et al. 2001 \\
\hline $\begin{array}{l}R B / R p i- \\
\quad b l b 1\end{array}$ & S. bulbocastanum & 8 & Map based & Cloned & $\begin{array}{l}\text { Naess et al. 2000; Song } \\
\text { et al. 2003; van der } \\
\text { Vossen et al. } 2003\end{array}$ \\
\hline Rpi-ptal & S. papita & 8 & Allele mining & $\begin{array}{l}\text { Cloned ortholog } \\
\text { of Rpi-blb1 }\end{array}$ & $\begin{array}{l}\text { Vleeshouwers et al. 2008; } \\
\text { Wang et al. } 2008\end{array}$ \\
\hline Rpi-plt1 & S. polytrichon & 8 & Allele mining & $\begin{array}{l}\text { Ortholog of } \\
\text { Rpi-blb1 }\end{array}$ & Wang et al. 2008 \\
\hline Rpi-sto1 & S. stoloniferum & 8 & Allele mining & $\begin{array}{l}\text { Cloned ortholog } \\
\text { of Rpi-blb1 }\end{array}$ & $\begin{array}{l}\text { Vleeshouwers et al. 2008; } \\
\text { Wang et al. } 2008\end{array}$ \\
\hline Rpi-mcq1 & S. mochiquense & 9 & Map based & & Smilde et al. 2005 \\
\hline $\begin{array}{l}\text { Rpi-vnt1.1 } \\
\text { Rpi-vnt1.3 }\end{array}$ & S. venturii & 9 & Allele mining & Tm-2 homologs & $\begin{array}{l}\text { Foster et al. 2009; Pel } \\
\text { et al. } 2009\end{array}$ \\
\hline Rpi-phul & S. phureja & 9 & Map based & & Śliwka et al. 2006 \\
\hline$R_{\text {ber }}$ & S. berthaultii & 10 & Map based & & Rauscher et al. 2006 \\
\hline
\end{tabular}


Table 1 (continued)

\begin{tabular}{|c|c|c|c|c|c|}
\hline Gene & Origin & LG & $\begin{array}{l}\text { Cloning } \\
\text { strategy }\end{array}$ & $\begin{array}{l}\text { Additional } \\
\text { information }\end{array}$ & References \\
\hline Rpi-mcd & S. microdontum & 10 & Map based & $\begin{array}{l}\text { Accession } \\
\text { MCD178 }\end{array}$ & Sandbrink et al. 2000 \\
\hline \multirow[t]{3}{*}{ Rpi-pcs } & S. paucissectum & 11 & Map based & $\begin{array}{l}\text { Other found on } \\
\text { LG } 10 \text { and } 12\end{array}$ & Villamon et al. 2005 \\
\hline & S. microdontum & $?$ & Map based & Incomplete map & Bisognin et al. 2005 \\
\hline & S. caripense & 9 & Map based & Incomplete map & $\begin{array}{l}\text { Nakitandwe et al. } 2007 \mathrm{a} \text {; } \\
\text { Nakitandwe et al. } 2007 \mathrm{~b}\end{array}$ \\
\hline
\end{tabular}

(UHD) potato reference map (Ritter et al. 2008). The map and the additional markers generated will aid the mapping of $R$ genes.

\section{Cloning of Resistance Genes by Map-based Cloning and Allele Mining Strategies}

Map-based cloning of four Rpi genes has been published prior to BIOEXPLOIT: R1 (Ballvora et al. 2002) and $R 3 a$ (Huang et al. 2005) from $S$. demissum as well as $R B$ or Rpi-blb1 (Song et al. 2003; van der Vossen et al. 2003) and Rpi-blb2 (van der Vossen et al. 2005) from the Mexican diploid species $S$. bulbocastanum. The latter two genes confer resistance to a wide range of $P$. infestans isolates, giving hope that these genes will provide a more durable resistance than the $S$. demissum $R$ genes. All four of these genes possess a 'coiled coil' domain, nucleotide binding site and leucine rich repeats (CC-NB-LRR), one of the more frequent classes of plant $R$ genes.

As is often the case with plant $R$ genes, the isolated genes are found within clusters of evolutionarily-related paralogs and/or other $R$ genes. For example Rpi-blb1 resides on LG VIII in a resistance gene analogue (RGA) cluster of four members (Song et al. 2003; van der Vossen et al. 2003). Rpi-blb2, located on LG VI, was identified within a cluster of at least 15 RGAs with homology to $M i-1$ which, in tomato, confers resistance to nematodes, aphids and white flies (van der Vossen et al. 2005). Similarly, $R l$ is located within an $R$ gene rich region on LG V that not only comprises different, fast evolving $R l$ paralogs but also two other $R$ gene families with homology to Prf and Bs4 from tomato (Ballvora et al. 2002; Kuang et al. 2005). In line with this finding, at least two genes $(\mathrm{H1}, \mathrm{GroV1})$ conferring resistance towards potato cyst nematode $(\mathrm{PCN})$ as well as $R x 2$ and $N b$ for resistance to potato virus X (PVX) were also found on LG VIII (reviewed by Gebhardt and Valkonen 2001).

Similarly, previous studies have shown that $R 6, R 7, R 10$ and $R 11$ co-localize with $R 3 a$ and $R 3 b$ on LG XI (El-Kharbotly et al. 1996; Huang et al. 2004; Huang 2005; Bradshaw et al. 2006a). Further phenotypic studies of allelic variations of the $R 3$ complex identified nine allelic versions of the $R 3 a$ gene, implying that several of the as yet uncloned $S$. demissum $R$ genes may be allelic variants of $R 3 a$ (Huang 2005). In tomato, the complex $I 2$ locus yielding resistance towards Fusarium oxysporum $\mathrm{f}$ 
sp lycopersici has been cloned from this region and contains one active gene and six RGAs (Simons et al. 1998).

The property of $R$ gene clustering, allied to the observation that the potato genome appears to contain a relatively small number of resistance 'hot spots', suggests a way forward in the isolation of more Rpi genes in the near future. For example, 14 of 19 important $R$ genes for resistance to pathogens such as viruses, nematodes and $P$. infestans were found in five $R$ gene-rich regions (Gebhardt and Valkonen 2001). It is possible that other genes, unrelated to $R$ genes, found within or proximal to such clusters may also play a role in quantitative resistance. Clustering makes it difficult to resolve the specific contribution of these "other genes" to observed resistance. Unbiased approaches such as the use of regional genomic arrays are currently being used within the BIOEXPLOIT project to identify novel candidate genes within known regions containing genes for quantitative resistance. In support of this concept natural variant alleles of a potato allene oxide synthase 2 (STAOS2) mapping to a quantitative resistance locus (QRL) on chromosome XI have been shown to complement a null Arabidopsis aos mutant, increasing levels of various defence-related proteins, such as jasmonates as well as resistance to Arabidopsis pathogens (Pajerowska-Mukhtar et al. 2008).

The often conserved gene sequence structure within $R$ gene clusters has led to the concept of "allele mining" for Rpi genes, as map-based cloning is still a relatively labour intensive approach. The high levels of sequence conservation between RGAs at any given $R$ gene locus, suggest the possibility that PCR can be used to amplify homologous/paralogous candidate $R p i$ genes from any given locus, once the resistance has been mapped and sequence information about the type of $R$ genes within the loci is available. As outlined below, allele mining has been applied to identify paralogous (homologous genes within the same species) and orthologous genes (homologous genes between species).

It has been known for some time that certain domains such as the P-loop (Saraste et al. 1990), kinase-2 motif (Traut 1994) and the GLPL motif (Meyers et al. 1999) within the NBS part of $R$ genes are highly conserved. In potato, this information has been used to PCR-amplify, among others, $R$ gene fragments linked to $P$. infestans $R 7$ resistance on LG XI (Leister et al. 1996) and subsequently further refined to obtain molecular markers based on $R$ gene variations within genomes in an approach referred to as "NBS-profiling" (van der Linden et al. 2004).

To amplify full-length $R$ genes, allele mining was first utilized to clone $R B$ from $S$. bulbocastanum (Song et al. 2003). Following a map based cloning approach, it was found that all of the BAC clones containing the target locus corresponded to the susceptible ' $r b$ ' allele. Gene sequences from these BAC clones allowed a 'longrange PCR' approach whereby the $R B$ gene was identified amongst four RGAs from the resistant parent (Song et al. 2003). The allelic, but functionally equivalent Rpiblb1 gene (van der Vossen et al. 2003) and the unrelated Rpi-blb2 gene (van der Vossen et al. 2005) were further used to PCR amplify orthologues in additional Solanum species showing late blight resistance (Wang et al. 2008). This study, which is part of BIOEXPLOIT, identified the Rpi-blb1 homologs Rpi-sto1, Rpi-plt1, Rpiptal and Rpi-pta2 from S. stoloniferum, S. polytrichon and S. papita respectively but did not yield homologs from Rpi-blb2. The authors confirmed genetically that Rpi-stol and Rpi-plt1 reside in the same position on LG VIII as Rpi-blb1. Further 
effector based studies by Vleeshouwers et al. (2008) (detailed below) have shown that Rpi-stol and Rpi-ptal are indeed functionally equivalent to Rpi-blb1. The implications of these studies are two-fold. Firstly, the genomic organisation of the Rpi-blb1 gene cluster has been revealed and it is apparent that the Rpi-blb1 locus was present prior to the divergence of tuber-bearing and non-tuber-bearing Solanum species. Furthermore, presence of Rpi-blbl orthologues is linked to the flanking RGAs $R G A 1-b l b$ and RGA3-blb albeit both RGAs can be found without the presence of Rpi-blb1. Secondly, in terms of breeding prospects, introgression of Rpi genes from Solanum species such as $S$. bulbocastanum that cannot be crossed readily with cultivated $S$. tuberosum, can be circumvented by choosing more amenable species (e.g., S. stoloniferum) that carry functional $R$ gene orthologues. One less optimistic conclusion from these studies is the possibility that, despite the diverse array of potato wild species available to the breeder, the number of distinct functional Rpi genes maybe somewhat smaller than was previously supposed. It also highlights the need to employ all available taxonomic information when designing introgression programmes for Rpi genes.

A very effective use of an allele mining approach has recently been demonstrated (Foster et al. 2009; Pel et al. 2009) in the BIOEXPLOIT project. These groups used sequence information from the Tm-2 locus of tomato, which confers resistance to Tomato Mosaic Virus, to isolate candidate genes from the potato species S. venturii. Mapping of the chromosome IX locus had been achieved with the help of NBS profiling. Rpi-vnt1.1 and Rpi-vnt1.3 belong to the coiled-coil NBS leucine-rich repeat (LRR) class of $R$ genes, and their peptides are 75\% identical to the tomato Tm-2 protein. These authors also isolated Rpi-phul, from the primitive cultivated species S. phureja, and interestingly, this gene was identical to Rpi-vnt1.1, suggesting the possibility of introgression between the two species at some previous date.

Transcribed orthologues of $R B$ have also been 'mined' from a set of $S$. verrucosum accessions differing in their responses to P. infestans infection (Liu and Halterman 2006). Stable transformation of a susceptible $S$. tuberosum by one of the $R B$ orthologues from the late blight resistant $S$. verrucosum accession PI275260 conferred resistance to $P$. infestans. The functional $S$. verrucosum $R B$ gene contains an insertion of a complete leucine rich repeat when compared to the $R B$ gene from $S$. bulbocastanum, and differs from a susceptible $S$. verrucosum orthologue at only four amino acid residues (Liu and Halterman 2006).

In addition to the above described $R$ genes, an additional race-specific $R$ gene, Rpi-blb3 from $S$. bulbocastanum, has been cloned using a map-based cloning approach and subsequently used for allele mining (Lokossou et al. 2009). Rpi-blb3 has previously been mapped to LG IV and appears to be part of a large cluster of $R$ genes comprising $R 2$ from $S$. demissum, $R 2$-like from an $S$. demissum-free background and Rpi-abpt from S. bulbocastanum (Park et al. 2005a; Park et al. 2005b). Functional orthologues of Rpi-blb3 have been identified in these species by allele mining. Similar to Rpi-blb1, Rpi-stol and Rpi-ptal, effector-based studies with Avr2 (J.G. Morales et al., unpublished results) have shown that R2, R2-like and Rpi$a b p t$ are indeed functionally equivalent to Rpi-blb3 (Lokossou et al. 2009).

Three BIOEXPLOIT projects are focusing on cloning Rpi genes from LG 4 and comprise Rpi-bst1 from S. brachistotrichum (Z. Chu and J. Jones, personal communication), Rpi-mcdl from S. microdontum (Tan et al. 2008) and Rpi-dmsfl, 
a gene comprising a large component of a quantitative source of 'field' resistance probably derived from S. demissum (Bradshaw et al. 2004a; Hein et al. 2007). Genetic studies indicate that these resistances map within close proximity of Rpiblb3 and the associated genes R2, Rpi-R2-like and Rpi-abpt. Interestingly, Rpi-mcd1 and $R p i-d m s f 1$ have both been associated with field resistance, a quantitative resistance thought to be race non-specific and polygenically inherited (Bradshaw and Birch 2006; Bradshaw et al. 2004a, b; Bradshaw et al. 2006b; Tan et al. 2008). To isolate Rpi-dmsfl, a BAC library from a diploid potato clone expressing quantitative field resistance has been generated and screened with RGA probes derived from a tomato BAC clone (accession AF411807) linked to the $R 2$ cluster (Park et al. 2005b). Full length Rpi-blb3-like genes have been amplified from positively identified BAC clones, genomic DNA and cDNA (Hein et al. 2007; I. Hein et al., unpublished data) and function for these candidate genes is currently being sought.

\section{Perspectives}

Recent potato growing seasons have brought new challenges to the quest for resistance as a radical change in the $P$. infestans population structure is currently taking place across many European potato growing regions (Cooke et al. 2007a, b). A marked increase in the frequency of the A2 mating type has been reported in the Netherlands, France and the UK (Cooke et al. 2007a; Detourne et al. 2007; van Raaij et al. 2007) with wide-ranging short and long-term implications to the sustainability of blight control. This increase in A2 is dominated by a single clonal lineage, referred to as 'blue 13' or 'BPC06_3928A' that appears to be more aggressive than resident pathogen genotypes. In Great Britain, for example, SSR genotyping of almost 2,500 isolates has confirmed an increase in frequency from 12 to $70 \%$ of the population over three growing seasons from 2005 to 2007 (Cooke et al. 2007b). This lineage is also widespread in Germany, France and the Netherlands and has recently been found in Northern Ireland, Spain and Portugal (Cooke et al. 2007a).

In response to this threat, material previously identified as resistant to $P$. infestans is currently being re-screened with contemporary isolates including 'blue 13 ' to establish if the underlying $R$ genes are still able to confer resistance. Furthermore, continuous screening of gene bank material such as the Commonwealth Potato Collection (CPC), hosted at the Scottish Crop Research Institute (SCRI), routinely includes these new isolates in addition to complex older resident isolates.

It is a very exciting time to be working in the field of plant disease resistance as genome sequence initiatives for both the plant and the pathogen already have, and will continue to provide information for studying the complex processes leading to resistance (if the plant recognises the invading pathogen) or to susceptibility (if the plant's defences are evaded by pathogen variations). The discovery of a conserved amino acid sequence, RXLR, found originally in the oomycete effectors Avr $3 a$ (Armstrong et al. 2005) and Atrl (Armstrong et al. 2005; Rehmany et al. 2005; Whisson et al. 2007) provide molecular insights into the evolution of oomycete pathogenesis and the host response. Analysis of fully sequenced oomycetes $P$. sojae, $P$. ramorum, Hyaloperonospora arabidopsidis (formerly $H$. parasitica) and $P$. infestans has revealed hundreds of potential secreted effectors containing the 
RXLR motif (Tyler et al. 2006; Whisson et al. 2007; Win et al. 2007). These predicted effectors provide invaluable tools to: a) characterise $R$ genes and b) to identify resistance mechanisms that have the potential to be durable. Recently, Vleeshouwers et al. (2008) tested recognition of ten phylogenetically diverse Solanum genotypes from eight wild species, all resistant to various late blight isolates, towards 54 RXLR effectors that were transiently expressed in the respective genotypes using Potato Virus $X$ (PVX). Interestingly, the small effector family IpiO, consisting of at least two members, IpiO1 and IpiO2, is recognised by Solanum bulbocastanum carrying Rpi-blb1. Co-infiltration of Rpi-blb1 and IpiO in $N$. benthamiana resulted in a strong hypersensitive response (HR) and confirmed that IpiO is Avr-blb1 (Vleeshouwers et al. 2008). Transient expression of IpiO in the distantly related species $S$. stoloniferum and $S$. papita also induced a HR and allele mining for Rpi-blb1-like genes in these species identified Rpi-stol and Rpi-ptal, respectively (Vleeshouwers et al. 2008; Wang et al. 2008). Sequence analysis and comparison with Rpi-blb1 revealed only three and five non-synonymous nucleotide polymorphisms for Rpi-stol and Rpi-ptal respectively, which have been shown to be functionally equivalent to Rpi-blbl as all three genes recognised IpiO in transient Nicotiana benthamiana co-infiltration assays and yielded an HR response. This study has given a surprising insight into $R$ gene redundancy within Solanum species and has revealed that many of the resistances identified in wild species could potentially be mediated by orthologous genes and that effectors can be used to determine the recognition spectra of (orthologous) $R$ genes. IpiO1 and IpiO2 appear to be present in the majority of European and North-American P. infestans isolates which could explain the relatively broad-spectrum resistance conferred by Rpi-blb1 and the orthologues Rpi-stol, Rpi-ptal as well as Rpi-plt1 from S. polytrichon (Vleeshouwers et al. 2008; Wang et al. 2008).

In a paradigm shift and in line with the above findings, Birch et al. (2008) have proposed that understanding effector diversity in oomycete populations, as well as effector expression and function, can be used to drive a search for more durable sources of resistance. Invariant and functionally non-redundant effectors that are required for pathogenicity could provide the pathogen's 'Achilles heel'. Deployment of cognate $R$ genes that recognise these effectors could yield a more durable form of resistance than $R$ genes that target non-conserved and functionally redundant effectors, assuming that additional effectors from the pathogen do not interfere with the recognition event, or with processes downstream of the recognition event that lead, for example, to the HR (Birch et al. 2008).

Future deployment in potato improvement programmes of newly discovered resistance genes is an important issue. The aforementioned ongoing rapid shifts in $P$. infestans population structure render the conventional 'introgression' route, whereby it may take several years to introduce resistance genes into an adapted background, ineffective in combating this dynamic threat. The recent rapid progress in mapping and isolating newly discovered P. infestans resistance genes (notably in the BIOEXPLOIT project) leads to the possibility of more rapid deployment through a transgenic or 'cisgenic' route (Jacobsen and Schouten 2007; Schouten and Jacobsen 2008). The development of this option is dependent on changes in regulations regarding field deployment, current legislation being based on risk assessments with transgenes originating from non-crossable species. 'Cisgenes' are 
genes derived from crop plants themselves or from crossable species. There are now several 'marker-free' methods for potato transformation, and it can be argued that cisgenesis is a 'cleaner' method for gene introgression than conventional methods, such as induced translocation and introgression breeding, which have problems associated with linkage drag. Thus, there is a compelling argument for exempting cisgenesis from current regulations on genetically modified organisms. This would greatly facilitate the rapid deployment of new resistances against $P$. infestans, either singly, in combinations or as 'mixtures'. Such a development would allow the modern potato breeder a realistic chance of combating the threat posed by $P$. infestans, and perhaps more importantly, would lead to a more sustainable potato crop (i.e. less applied chemicals) in regions where $P$. infestans is endemic.

\section{References}

Armstrong MR, Whisson SC, Pritchard L, Bos JIB, Venter E, Avrova AO, Rehmany AP, Böhme U, Brooks K, Cherevach I, Hamlin N, White B, Fraser A, Lord A, Quail MA, Churcher C, Hall N, Berriman M, Huang S, Kamoun S, Beynon JL, Birch PRJ (2005) An ancestral oomycete locus contains late blight avirulence gene Avr $3 a$, encoding a protein that is recognized in the host cytoplasm. Proc Natl Acad Sci USA 102:7766-7771

Ballvora A, Ercolano MR, Weiss J, Meksem K, Bormann CA, Oberhagemann P, Salamini F, Gebhardt C (2002) The RI gene for potato resistance to late blight (Phytophthora infestans) belongs to the leucine zipper/NBS/LRR class of plant resistance genes. Plant J 30:361-371

Birch PRJ, Boevink PC, Gilroy EM, Hein I, Pritchard L, Whisson SC (2008) Oomycete RXLR effectors: delivery, functional redundancy and durable disease resistance. Curr Opin Plant Biol 11:373-379

Bisognin DA, Douches DS, Buszka L, Bryan G, Wang D (2005) Mapping Late Blight Resistance in Solanum microdontum Bitter. Crop Sci 45:340-345

Black W, Mastenbroek C, Mills WR, Peterson LC (1953) A proposal for an international nomenclature of races of Phytophthora infestans and of genes controlling immunity in Solanum demissum derivatives. Euphytica 2:173-179

Bradshaw JE, Birch PRJ (2006) Breeding potatoes in Scotland for resistance to late blight. Proceedings Crop Protection in Northern Britain, pp 249-253

Bradshaw JE, Bryan GJ, Hackett CA, McLean K, Pande B, Stewart HE, Waugh R (2004a) Dissection and analysis of quantitative disease resistance in tetraploid potato. Euphytica 137:13-18

Bradshaw JE, Pande B, Bryan GJ, Hackett CA, McLean K, Stewart HE, Waugh R (2004b) Interval mapping of quantitative trait loci for resistance to late blight [Phytophthora infestans (Mont.) de Bary], height and maturity in a tetraploid population of potato (Solanum tuberosum subsp. tuberosum). Genetics 168:983-995

Bradshaw JE, Bryan GJ, Lees AK, McLean K, Solomon-Blackburn RM (2006a) Mapping the R10 and $R 11$ genes for resistance to late blight (Phytophthora infestans) present in the potato (Solanum tuberosum) R-gene differentials of Black. Theor Appl Genet 112:744-751

Bradshaw JE, Hackett CA, Lowe R, McLean K, Stewart HE, Tierney I, Vilaro MD, Bryan GJ (2006b) Detection of a quantitative trait locus for both foliage and tuber resistance to late blight [Phytophthora infestans (Mont.) de Bary] on chromosome 4 of a dihaploid potato clone (Solanum tuberosum subsp. tuberosum). Theor Appl Genet 113:943-951

Cooke DEL, Lees AK, Hansen JG, Lassen P, Andersson B, Bakanyi J (2007a) EUCABLIGHT one year on: an update on the European blight population database. Proceedings of the 10th workshop of an European network for the development of an integrated control strategy for late blight-PPO special report 12:129-136

Cooke DEL, Lees AK, Shaw DS, Taylor M, Prentice MWC, Bradshaw NJ, Bain RA (2007b) Survey of GB Blight Populations. Proceedings of the 10th workshop of an European network for the development of an integrated control strategy for late blight_-PPO special report 12:145-152

Danan, S. et al. (2009) Search for novel late blight quantitative resistance sources in potato: QTL mapping of stem and foliage resistance traits in the wild species Solanum sparsipilum and Solanum spegazzinii. Submitted 
Detourne D, Dubois L, Duvauchelle S (2007) The evolution of Phytophthora infestans in France (mating type, metalaxyl resistance). Proceedings of the EAPR Pathology Section seminar, 2-6 July 2007, Hattula, Finland. Agrifood Research Working papers 142. MTT Agrifood Research, Finland, p 17

Drenth A, Tas ICQ, Govers F (1994) DNA fingerprinting uncovers a new sexually reproducing population of Phytophthora infestans in the Netherlands. Eur J Plant Pathol 100:97-107

El-Kharbotly A, Palomino-Sánchez C, Salamini F, Jacobsen E, Gebhardt C (1996) $R 6$ and $R 7$ alleles of potato conferring race-specific resistance to Phytophthora infestans (Mont.) de Bary identified genetic loci clustering with the $R 3$ locus on chromosome XI. Theor Applied Gen 92:880-884

Foster SJ, Park TH, Pel M, Brigneti G, Sliwka J, Jagger L, van der Vossen EAG, Jones JD (2009) Rpivnt1.1, a Tm-22 homolog from Solanum venturii, confers resistance to potato late blight. Mol Plant Microbe Interact 22:589-600

Gebhardt C, Valkonen JPT (2001) Organization of genes controlling disease resistance in the potato genome. Ann Rev Phytopathol 39:79-102

Hein I, McLean K, Chalhoub B, Bryan GJ (2007) Generation and screening of a BAC library from a diploid potato clone to unravel durable late blight resistance on linkage group IV. Int J Plant Genomics 2007:51421

Huang S (2005) The discovery and characterization of the major late blight resistance complex in potatogenomic structure, functional diversity, and implications. PhD Thesis-Wageningen University, The Netherlands

Huang S, Vleeshouwers VG, Werij JS, Hutten RC, van Eck HJ, Visser RG, Jacobsen E (2004) The R3 resistance to Phytophthora infestans in potato is conferred by two closely linked $R$ genes with distinct specificities. Mol Plant Microbe Interact 17:428-435

Huang S, van der Vossen EAG, Kuang H, Vleeshouwers VG, Zhang N, Borm TJ, van Eck HJ, Baker B, Jacobsen E, Visser RG (2005) Comparative genomics enabled the isolation of the $R 3 a$ late blight resistance gene in potato. Plant $\mathrm{J} 42: 251-261$

Jacobsen E, Schouten HJ (2007) Cisgenesis strongly improves introgression breeding and induced translocation breeding of plants. Trends Biotechnol 25:219-223

Kuang H, Wei F, Marano MR, Wirtz U, Wang X, Liu J, Shum WP, Zaborsky J, Tallon LJ, Rensink W, Lobst S, Zhang P, Tornqvist C-E, Tek A, Bamberg J, Helgeson J, Fry W, You F, Luo M-C, Jiang J, Buell CR, Baker B (2005) The Rl resistance gene cluster contains three groups of independently evolving, type I $R 1$ homologues and shows substantial structural variation among haplotypes of Solanum demissum. Plant J 44:37-51

Kuhl JC, Hanneman RE Jr, Havey MJ (2001) Characterization and mapping of Rpil, a late-blight resistance locus from diploid (1EBN) Mexican Solanum pinnatisectum. Mol Gen Genet 265:977-985

Leister D, Ballvora A, Salamini F, Gebhardt C (1996) A PCR-based approach for isolating pathogen resistance genes from potato with potential for wide application in plants. Nat Genet 14:421-429

Leonards-Schippers C, Gieffers W, Salamini F, Gebhardt C (1992) The Rl gene conferring race-specific resistance to Phytophthora infestans in potato is located on potato chromosome V. Mol Gen Genet 233:278-283

Li X, van Eck HJ, Rouppe van der Voort JNAM, Huigen DJ, Stam P, Jacobsen E (1998) Autotetraploids and genetic mapping using common AFLP markers: the $R 2$ allele conferring resistance to Phytophthora infestans mapped on potato chromosome 4. Theor Appl Genet 96:1121-1128

Liu Z, Halterman D (2006) Identification and characterization of RB-orthologous genes from the late blight resistant wild potato species Solanum verrucosum. Phys Mol Plant Pathol 69:230-239

Lokossou AA, Park T-H, van Arkel G, Arens M, Ruyter-Spira C, Morales J, Whisson SC, Birch PRJ, Visser RGF, Jacobsen E, van der Vossen EAG (2009) Exploiting knowledge of $R / A v r$ genes to rapidly clone a new LZ-NBS-LRR family of late blight resistance genes from potato linkage group IV. Mol Plant Microbe Interact 22:630-641

Malcolmson JF, Black W (1966) New $R$ genes in Solanum demissum Lindl. and their complementary races of Phytophthora infestans (Mont.) de Bary. Euphytica 15:199-203

Meyers BC, Dickerman AW, Michelmore RW, Sivaramakrishnan S, Sobral BW, Young ND (1999) Plant disease resistance genes encode members of an ancient and diverse protein family within the nucleotide-binding superfamily. Plant J 20:317-332

Naess SK, Bradeen JM, Wielgus SM, Haberlach GT, McGrath JM, Helgeson JP (2000) Resistance to late blight in Solanum bulbocastanum is mapped to chromosome 8. Theor Appl Genet 101:697-704

Nakitandwe J, Trognitz F, Trognitz B (2007a) Reliable allele detection using SNP-based PCR primers containing Locked Nucleic Acid: application in genetic mapping. Plant Methods, 3. doi:10.1186/ 1746-4811-3-2 
Nakitandwe J, Trognitz FCH, Trognitz BR (2007b) Genetic mapping of Solanum caripense, a wild relative of pepino dulce, tomato and potato, and a genetic resource for resistance to potato late blight. Acta Hort 745:333-342

Pajerowska-Mukhtar KM, Mukhtar MS, Guex N, Halim VA, Rosahl S, Somssich IE, Gebhardt C (2008) Natural variation of potato allene oxide synthase 2 causes differential levels of jasmonates and pathogen resistance in Arabidopsis. Planta 228:293-306

Park TH, Gros J, Sikkema A, Vleeshouwers VG, Muskens M, Allefs S, Jacobsen E, Visser RG, van der Vossen EAG (2005a) The late blight resistance locus Rpi-blb3 from Solanum bulbocastanum belongs to a major late blight $R$ gene cluster on chromosome 4 of potato. Mol Plant-Microb Interact 18:722729

Park TH, Vleeshouwers VG, Huigen DJ, van der Vossen EAG, van Eck HJ, Visser RG (2005b) Characterization and high-resolution mapping of a late blight resistance locus similar to $R 2$ in potato. Theor Appl Genet 111:591-597

Pel MA, Foster SJ, Park TH, Rietman H, van Arkel G, Jones JD, Van Eck HJ, Jacobsen E, Visser RG, Van der Vossen EAG (2009) Mapping and cloning of late blight resistance genes from Solanum venturii using an interspecific candidate gene approach. Mol Plant Microbe Interact 22:601-615

Rauscher GM, Smart CD, Simko I, Bonierbale M, Mayton H, Greenland A, Fry WE (2006) Characterization and mapping of Rpi-ber, a novel potato late blight resistance gene from Solanum berthaultii. Theor Appl Genet 112:674-687

Rehmany AP, Gordon A, Rose LE, Allen RL, Armstrong MR, Whisson SC, Kamoun S, Tyler BM, Birch PRJ, Beynon JL (2005) Differential recognition of highly divergent downy mildew avirulence gene alleles by RPP1 resistance genes from two Arabidopsis lines. Plant Cell 17:1839-1850

Ritter E, Ruiz de Galarreta JI, van Eck HJ, Sanchez I (2008) Construction of a potato transcriptome map based on the cDNA-AFLP technique. Theor Appl Genet 116:1003-1013

Sandbrink JM, Colon LT, Wolters PJCC, Stiekema WJ (2000) Two related genotypes of Solanum microdontum carry different segregating alleles for field resistance to Phytophthora infestans. Mol Breeding 6:215-225

Saraste M, Sibbald PR, Wittinghofer A (1990) The P-loop - a common motif in ATP- and GTP-binding proteins. Trends Biochem Sci 15:430-434

Schouten HJ, Jacobsen E (2008) Cisgenesis and intragenesis, sisters in innovative plant breeding. Trends Plant Sci 13:260-261

Shattock RC, Janssen BD, Whitbread R, Shaw DS (1977) An interpretation of the frequencies of hostspecific phenotypes of Phytophthora infestans in North Wales. Ann Appl Biol 86:249-260

Simons G, Groenendijk J, Wijbrandi J, Reijans M, Groenen J, Diergaarde P, Van der Lee T, Bleeker M, Onstenk J, de Both M, Haring M, Mes J, Cornelissen B, Zabeau M, Vos P (1998) Dissection of the Fusarium $I 2$ gene cluster in tomato reveals six homologs and one active gene copy. Plant Cell 10:1055-1068

Śliwka J, Jakuczun H, Lebecka R, Marczewski W, Gebhardt C, Zimnoch-Guzowska E (2006) The novel, major locus Rpi-phul for late blight resistance maps to potato chromosome IX and is not correlated with long vegetation period. Theor Appl Genet 113:685-695

Smilde WD, Brigneti G, Jagger L, Perkins S, Jones JD (2005) Solanum mochiquense chromosome IX carries a novel late blight resistance gene Rpi-mocl. Theor Appl Genet 110:252-258

Song J, Bradeen JM, Naess SK, Raasch JA, Wielgus SM, Haberlach GT, Liu J, Kuang H, Austin-Phillips S, Buell CR, Helgeson JP, Jiang J (2003) Gene RB cloned from Solanum bulbocastanum confers broad spectrum resistance to potato late blight. Proc Natl Acad Sci USA 100:9128-9133

Tan MYA, Hutten RCB, Celis C, Park TH, Niks RE, Visser RGF, van Eck HJ (2008) The Rpi-mcd1 locus from Solanum microdontum involved in resistance to Phytophthora infestans, causing a delay in infection, maps on potato chromosome 4 in a cluster of NBS-LRR genes. Mol Plant Microbe Interact 21:909-918

Traut TW (1994) The functions and consensus motifs of nine types of peptide segments that form different types of nucleotide-binding sites. Eur J Biochem 222:9-19

Tyler BM, Tripathy S, Zhang X, Dehal P, Jiang RHY, Aerts A, Arredondo FD, Baxter L, Bensasson D, Beynon JL, Chapman J, Damasceno CMB, Dorrance AE, Dou D, Dickerman AW, Dubchak IL, Garbelotto M, Gijzen M, Gordon SG, Govers F, Grunwald NJ, Huang W, Ivors KL, Jones RW, Kamoun S, Krampis K, Lamour KH, Lee MK, McDonald WH, Medina M, Meijer HJG, Nordberg EK, Maclean DJ, Ospina-Giraldo MD, Morris PF, Phuntumart V, Putnam NH, Rash S, Rose JKC, Sakihama Y, Salamov AA, Savidor A, Scheuring CF, Smith BM, Sobral BWS, Terry A, Torto-Alalibo TA, Win J, Xu Z, Zhang H, Grigoriev IV, Rokhsar DS, Boore JL (2006) Phytophthora genome sequences uncover evolutionary origins and mechanisms of pathogenesis. Science 313:1261-1266 
van der Linden CG, Wouters DCAE, Mihalka V, Kochieva EZ, Smulders MJM, Vosman B (2004) Efficient targeting of plant disease resistance loci using NBS profiling. Theor Appl Genet 109:384393

van der Vossen EAG, Sikkema A, Hekkert BL, Gros J, Stevens P, Muskens M, Wouters D, Pereira A, Stiekema W, Allefs S (2003) An ancient $R$ gene from the wild potato species Solanum bulbocastanum confers broad-spectrum resistance to Phytophthora infestans in cultivated potato and tomato. Plant $\mathbf{J}$ 36:867-882

van der Vossen EAG, Gros J, Sikkema A, Muskens M, Wouters D, Wolters P, Pereira A, Allefs S (2005) The Rpi-blb2 gene from Solanum bulbocastanum is an $\mathrm{Mi}-1$ gene homolog conferring broad-spectrum late blight resistance in potato. Plant J 44:208-222

van Raaij HMG, Evenhuis A, van den Bosch GBM, Foerch MB, Spits HG, Kessel GJT, Flier WG (2007) Monitoring virulence and mating type of Phytophthora infestans in the Netherlands in 2004 and 2005. Proceedings of the 10th workshop of an European network for the development of an integrated control strategy for late blight-PPO special report 12:281-284

Villamon FG, Spooner DM, Orrillo M, Mihovilovich E, Perez W, Bonierbale M (2005) Late blight resistance linkages in a novel cross of the wild potato species Solanum paucissectum (series Piurana). Theor Appl Genet 111:1201-1214

Vleeshouwers VG, Rietman H, Krenek P, Champouret N, Young C, Oh SK, Wang M, Bouwmeester K, Vosman B, Visser RG, Jacobsen E, Govers F, Kamoun S, van der Vossen EAG (2008) Effector genomics accelerates discovery and functional profiling of potato disease resistance and Phytophthora infestans avirulence genes. PLoS ONE 3:e2875

Wang M, Allefs S, van den Berg RG, Vleeshouwers VG, van der Vossen EAG, Vosman B (2008) Allele mining in Solanum: conserved homologues of Rpi-blb1 are identified in Solanum stoloniferum. Theor Appl Genet 116:933-943

Whisson SC, Boevink PC, Moleleki L, Avrova AO, Morales JG, Gilroy EM, Armstrong MR, Grouffaud S, van West P, Chapman S, Hein I, Toth IK, Pritchard L, Birch PRJ (2007) A translocation signal for delivery of oomycete effector proteins into host plant cells. Nature 450:115-119

Win J, Morgan W, Bos J, Krasileva KV, Cano LM, Chaparro-Garcia A, Ammar R, Staskawicz BJ, Kamoun S (2007) Adaptive evolution has targeted the C-terminal domain of the RXLR effectors of plant pathogenic oomycetes. Plant Cell 19:2349-2369 